\title{
КРИМІНАЛЬНО-ПРАВОВА КВАЛІФІКАЦІЯ ПІДРОБЛЕННЯ ЗА СУКУПНІСТЮ ЗЛОЧИНІВ
}

Щирська В. С.

У статmі проаналізовано погляди з приводу особливостей кваліфікації окремих кримінально караних підроблень і кваліфікації викрадення шляхом підроблення документів взагалі, пропозиції відносно кваліфікації зазначених діянь, які висуваються в научі кримінального права. Завдяки підро бленню можливе створення сприятливих умов для подальшого заволодіння чужим майном. Підроблення й заволодіння чужим майном слід кваліфікувати за правилами реальної сукупності злочинів, що дає змогу дотриматися принципу повноти кримінально-правової кваліфікації, згідно з яким кримінально-правову оцінку повинні отримати всі значущі з точки зору кримінального закону дії. У кваліфікації за сукупністю відображено спричинення в результаті означених дій шкоди кільком об'єктам кримінально-правової охорони на відміну від підроблення й викрадення окремо одне від одного.

Ключові слова: повторність, кримінально каране підроблення, контрабанда, підроблені документи, правила кваліфікації, сукупність злочинів.

В статье проанализированы точки зрения по поводу особенностей квалификации отдельных уголовно наказуемых подделок и похищения путем подделки документов вообще, предложения относительно квалификации указанных деяний в науке уголовного права. Благодаря подделке возможно создание благоприятных условий для завладения чужим имуществом. Подделку и завладение чужим имуществом следует квалифицировать по правилам реальной совокупности преступлений, что позволяет соблюсти принцип полноты уголовно-правовой квалификации, согласно которому уголовно-правовую оценку должны получить все значимые с точки зрения уголовного закона действия. В квалификации по совокупности отражено причинение в результате указанных действий ущерба нескольким объектам уголовно-правовой охраны, в отличие от подделки и кражи отдельно друг от друга.

Ключевые слова: повторность, уголовно наказуемая подделка, контрабанда, поддельные документы, правила квалификации, совокупность преступлений.

The article analyzes the points of view regarding the peculiarities of the qualification of individual criminal offenses and the qualification of theft by falsifying documents in general, the significant proposals regarding the qualification of these actions, which are advanced in the science of criminal law. Due to the forgery, it is possible to create further favorable conditions for further seizure of someone else's property. Due to the forgery, it is possible to create further favorable conditions for further seizure of someone else's property. Counterfeiting and seizure of someone else's property should be qualified according to the rules of the real set of crimes, which allows observance of the principle of completeness of criminal-legal qualification, according to which the criminal-law assessment must be obtained by all significant in terms of the criminal law of action. The qualification reflects, in aggregate, the cause of the damage caused by the identified actions to several objects

Щирська В. С., 2019 of criminal protection, as opposed to counterfeiting and theft being separated from each other.

It was noted that the rules of qualification developed in the theory of criminal law and the rules of qualification of crimes, which are committed by the method of forgery specified in this section, can lead to incorrect qualification of actions of the guilty person, or even to bring the innocent to criminal responsibility.

Key words: repetition, criminal offense of forgery, smuggling, forged documents, rules of qualification, set of crimes.

Постановка проблеми та її актуальність. Одним із багатьох факторів, який ускладнює реалізацію управлінської функції держави, $\epsilon$ наявність зовнішніх втручань у порядок управління, у тому числі шляхом перекручування інформації в документах, які засвідчують юридично значущі факти. Суспільна небезпечність підроблення документів полягає в тому, що така поведінка завдає шкоди нормальній управлінській діяльності, порушує суспільні відносини у сфері документообігу, тим самим заважаючи компетентним управлінським органам та їх посадовим особам об'єктивно судити про дійсні права й обов'язки громадян, що своєю чергою може спричинити прийняття ними незаконних рішень.

За своєю сутністю кримінально каране підроблення майже завжди поєднано з подальшим використанням підробленої речі. Наявність певної мети (у більшості випадків це саме використання) перетворює «звичайне» підроблення на кримінально каране. На меті використання в разі підроблення наголошується в багатьох нормах Особливої частини КК України, в яких передбачена відповідальність. Саме у сполученні підроблення й подальшого використання підробки знаходить свій логічний вияв механізм заподіяння реальної шкоди охоронюваним кримінальним законом суспільним відносинам в результаті підроблення. Якою гарною не була б підробка, без їі подальшого використання або вчинення з нею інших дій (збуту, вилучення з законного обігу), реальної шкоди об'єкту кримінально-правової охорони не може бути завдано. 3 огляду на високу ймовірність такого поєднання в злочинній діяльності в більшості норм, що передбачають відповідальність за підроблення, однією з альтернативних форм учинення об'єктивної сторони складу злочину передбачена така форма, як використання підробленої речі. Не можна залишити без уваги норми, передбачені ст. ст. 200, 216, 224, 318 та іншими. Для кваліфікації подібних випадків можна сформулювати таке правило: підроблення з подальшим використанням підробки за умови передбачення використання як однієї з форм учинення відповідного складу злочину поряд з підробленням і не завдання шкоди іншому, аніж в разі самого підроблення, об'єкту, на охорону якого спрямована дія іншої кримінально-правової норми, вчинене слід кваліфіку- 
вати як одиничний злочин за статтею, яка передбачає відповідальність за підроблення.

Аналіз останніх досліджень і публікацій. У науці кримінального права завжди приділялася значна увага питанням кримінально-правової охорони управлінських відносин, зокрема відносин у сфері документообігу. Відповідальність за використання підробки може бути передбачена і в інших нормах, крім відповідальності за саму підробку. У такому випадку можна зазначити, що шкода від використання спричиняється відмінному від підроблення основному безпосередньому об'єкту. Тут використання виступає як спосіб учинення діяння, основна властивість якого вбачається в спрямованості на завдання шкоди іншому основному об'єкту, аніж у разі підроблення. В іншій нормі на використання як можливої форми вчинення об'єктивної сторони складу злочину або як способу вчинення відповідного злочину може бути прямо зазначено у диспозиції статті чи однозначно випливати під час ії тлумачення. У ч. 1 ст. 233 Кримінального кодексу (далі - КК) ідеться про відповідальність за приватизацію державного, комунального майна шляхом використання підроблених приватизаційних документів. Контрабанда (ст. 201 КК) може бути вчинена, окрім іншого, шляхом подання підроблених документів. Це випливає зі змісту диспозиції статті. Приховати від митного контролю під час переміщення предмети можна й через використання підроблених документів. Отже, поняттям «приховування від митного контролю» охоплюється й використання підроблених документів. Наполягається на такому й у керівних роз'ясненнях Пленуму Верховного Суду України [5, с. 11]. 3 огляду на це дещо спірною $\epsilon$ обрана у постанові № 8 від 3 червня 2005 р. позиція Пленуму Верховного Суду України, яка зводиться до того, що у випадках, коли вчинення контрабанди пов'язане з використанням підроблених документів, скоєне необхідно також кваліфікувати за ч. 3 ст. 358 Кк України [5, с. 12]. До речі, у постанові № 2 від 26 лютого 1999 р. «Про судову практику в справах про контрабанду та порушення митних правил» така позиція не знайшла свого відображення [6, с. 84]. Судова практика також виходить 3 того, що використання підроблених документів може бути способом вчинення контрабанди.

Під час дослідження питання кваліфікації підроблення й наступного використання підробки неможливо обійти увагою розмежування підроблення документів i їх використання, передбачене ст. 358 КК. На практиці в правозастосовних органах нерідко виникають складнощі в проведенні такого розмежування. Ці складнощі насамперед зумовлені правовою оцінкою дій особи, яка підробила документ, а згодом його використала.

Однією з гарантій законності у сфері кримінального правосуддя $\epsilon$ правильна кваліфікація злочинів, що передбачає однакове застосування кримінального закону до всіх злочинів одного виду незалежно від суб'єкта кваліфікації або місця вчинення злочину. [4, с. 437-441]. Разом з тим, суперечливою $\epsilon$ практика органів досудового розслідування й судів щодо кваліфікації підроблення документів i їх подальшого використання (ч. ч. 1, 3 ст. 358 КК). Річ у тім, що сфальсифікований документ може бути використаний як самим підроблювачем, так і іншою особою. Не виникає питань відносно кваліфікації вчиненого в разі використання підробленого документа осо- бою, яка його не підробляла. Дії такої особи потребують кваліфікації за ч. 3 ст. 358 КК як використання завідомо підробленого документа.

Слід погодитися з думкою В.М. Кудрявцева, що для того, щоб у конкретному кримінальному провадженні вирішити, маємо ми один злочин чи кілька, необхідно відокремити такий склад злочину, як використання підробленого документа. Видається, що законодавець мав на меті покарання саме тих, хто використовує такі документи, а не тих, хто їх підробив, а потім використав. Це виходить з того, що за таке діяння встановлене більш м'яке покарання, ніж за підроблення. Виходячи $з$ того, що безпосередні об'єкти «підроблення» й «використання», передбачені ч. ч. 1, 2 та 3 ст. 358 КК, $\epsilon$ тотожними, шкода об'єкту кримінально-правової охорони, що завдається у результаті використання підробки, буде врахована й за кваліфікації дій підроблювача за ч. 1 або 2 ст. 358 КК.

Склад злочину, визначений ч. 1 ст. 358 КК, передбачає підроблення документа саме «з метою використання його як підроблювачем, так і іншою особою». Тобто це підтверджує, що використання документа підроблювачем уже криміналізовано ч. 1 ст. 358 КК й не потребує додаткової кваліфікації за ч. 3 ст. 358 КК. Підроблюючи документ, особа усвідомлює, що документ може бути використаний у майбутньому, і це усвідомлення законодавець уже врахував у визначенні санкції за такий злочин.

Криміналізуючи саме підроблення, навіть без його використання, законодавець стояв, мабуть, на тій позиції, що саме підроблення створює небезпеку використання підробки замість справжньої речі. Отже, наслідком підроблення може бути використання підробки. У законі, в покаранні за підроблення, уже врахований такий наслідок від підроблення. Підроблення можна назвати ознакою формального складу злочину, де наслідок у вигляді можливого використання винесено за межі складу злочину. Підроблення $\epsilon$ закінченим з моменту створення підробленої речі, саме вже створення небезпеки використання робить підроблення кримінально караним.

Дії особи, яка підробила документ, а згодом його використала, потребують кваліфікації лише за ч. 1 або 2 ст. 358 КК. Особа, яка підробила документ, може відповідати за ч. 3 ст. 358 КК лише в тих випадках, коли вона не притягувалася до кримінальної відповідальності за підроблення. Наприклад, коли закінчилися строки давності притягнення до відповідальності за підроблення документа або коли в момент учинення підроблення особа ще не досягла віку, з якого настає кримінальна відповідальність за такий злочин, а використовує підроблені документи після досягнення відповідного віку.

Якщо проаналізувати деякі статті, які передбачають відповідальність за підроблення і $\epsilon$ спеціальними складами злочинів відносно ст. 358 КК, то можна побачити, що відповідальність (і це, мабуть, правильно) за використання підробленого документа передбачена у перших частинах цих статей як одна з альтернативних дій об'єктивної сторони складу злочину. Це такі, наприклад, статті, як ст. ст. 200, 216, 224, 318 КК. Беручи до уваги, що якісний кримінальний закон повинен мати єдиний підхід до опису ознак об'єктивної сторони однотипних злочинів, пропонуємо у ст. 358 КК передбачити 
використання завідомо підробленого документа як одну з альтернативних дій об'єктивної сторони цього злочину. До речі, такий підхід до опису зазначених злочинних дій використовується у КК Республіки Білорусь (ст. 380) [2, с. 227].

Запропонований варіант $\epsilon$ найбільш прийнятним. Можливим $\epsilon$ також викладення ч. 3 в наступній редакції «використання завідомо підробленого документа, підробленого іншою особою». Але таке рішення спричинить інші запитання. Наприклад, як бути з винною особою, коли спливли строки давності притягнення до відповідальності за підробку? За умов, що $\epsilon$ в чинному кодексі, таку особу слід притягнути до відповідальності за використання підробки (ч. 3 ст. 358 КК). А з пропонованими нововведеннями особа не буде суб'єктом цього злочину. Отже, така пропозиція $є$ неприйнятною.

Підсумовуючи викладене, можна зробити висновок про те, що дії особи, яка підробила документ, а згодом його використала, потребують кваліфікації лише за ч. 1 або 2 ст. 358 КК. Саме заради досягнення стабільності практики застосування кримінального закону, а отже й забезпечення законності у сфері кримінального правосуддя в аспекті кваліфікації дій особи, яка підробила документ, а згодом його використала, необхідно внести запропоновані зміни до ст. 358 КК.

Поруч з описаним вище дискусійним моментом кваліфікації підроблення треба розглянути ситуацію, коли особа використовує документ, який підроблений іншою особою на її прохання. Деякі науковці вважають, що така особа поряд з відповідальністю за використання підробленого документа, повинна також нести відповідальність за підбурювання до підроблення документів [7, с. 342]. Інші наполягають на тому, що у такому випадку дії винної особи не потребують додаткової кваліфікації ще й за використання завідомо підробленого документа [8, с. 19]. Більш привабливою вбачається саме друга точка зору. У такому випадку маємо справу зі співучастю в злочині, і згідно зі ст. 27 КК особа, яка безпосередньо підробляла документ, буде виконавцем, а особа, яка умовила вчинити підроблення, буде підбурювачем вчинення злочину, передбаченого ч. 1 ст. 358 КК. 3 огляду на те, що за ч. 3 ст. 358 КК може відповідати лише особа, яка не брала участі в підробленні документа, співучасник злочину, передбаченого ч. 1 ст. 358 КК, буде відповідати лише за підроблення документа. Дії винної особи не потребують додаткової кваліфікації за ч. 3 ст. 358 КК. Таким чином, особа, яка брала участь у вчиненні злочину, передбаченого ч. 1 ст. 358 КК, у ролі співучасника (організатора, підбурювача або пособника), а згодом використовує підроблений документ, нестиме відповідальність лише за участь у підробленні документа без додаткової кваліфікації за ч. 3 ст. 358 КК.

Метою статті $\epsilon$ розгляд кримінально-правової кваліфікації підроблення за сукупністю злочинів.

Виклад основного матеріалу. Проаналізувавши точки зору з приводу особливостей кваліфікації окремих кримінально караних підроблень і кваліфікації викрадення шляхом підроблення документів взагалі, що висуваються в науці кримінального права, можна виокремити деякі пропозиції відносно кваліфікації зазначених дій.

Домінантною в науці кримінального права $\epsilon$ точка зору про необхідність кваліфікувати за сукупністю [9, с. 19-29; 10, с. 387-389]. П̈ї прихильники вбачають в підробленні й подальшому заволодінні чужим майном за допомогою підробок реальну сукупність злочинів.

Окремі вчені вважають діаметрально протилежно. Так, П.С. Матишевський стверджує, що оскільки фальсифікація документів $\epsilon$ різновидом шахрайського обману, за допомогою якого винний створює уявну (зовнішню) правову підставу на отримання майна, таке заволодіння охоплюється ст. 83 КК 1960 р. і додаткової кваліфікації за ст. 194 КК 1960 р. не потребує [11, с. 68]. Т.Л. Сергєєва розглядала фальсифікацію документів як засіб посягання на державне або суспільне майно. I склад злочину фальсифікація документів охоплюється, на ії думку, єдиним складом - складом посягання на державне або суспільне майно [1, с. 125].

Точка зору Д. Гончарова полягає в тому, що у випадках, коли наявність документа сама по собі являє собою право власності або інше речове право, особа, яка вилучає за його допомогою чуже майно, повинна відповідати за розкрадання. У тому ж випадку, коли особа виготовляє документ, який потім використовується лише для полегшення доступу до майна, винний несе відповідальність за сукупністю: за підроблення й розкрадання [12, с. 13].

Підроблення може лише створювати сприятливі умови для подальшого вчинення викрадення чужого майна. Отже, підроблення й заволодіння чужим майном слід кваліфікувати за правилами реальної сукупності злочинів. Це також дасть змогу дотриматися принципу повноти кримінально-правової кваліфікації, згідно з яким кримінально-правову оцінку повинні отримати всі значущі з погляду кримінального закону дії. У кваліфікації за сукупністю буде відображено спричинення в результаті означених дій шкоди кільком об'єктам кримінально-правової охорони на відміну від підроблення й викрадення виокремлено одне від одного. А отже, буде врахована більша суспільна небезпечність поєднання таких дій.

Найбільш дискусійним в аспекті, що розглядається, $\epsilon$ питання кваліфікації підроблення грошей з подальшим їх оплатним збутом. 3 цього питання в науці кримінального права панують дві протилежні точки зору. Згідно з першою заволодіння чужим майном під час збуту підроблених грошей повністю охоплюється поняттям фальшивомонетництва й додаткової кваліфікації за злочин проти власності не потребує. Прихильники цього погляду на свою користь наводять такі аргументи: збут підроблених грошей являє собою вид шахрайського обману, який передбачений спеціальною нормою, і тому загальні норми про шахрайство до нього не застосовуються [13, с. 138]; специфічність об'єкта й предмета злочину, що передбачає відповідальність за збут підроблених грошей [14, с. 12]; склад збуту передбачає можливість отримання будь-яких цінностей, адже можливість грошей слугувати законним платіжним засобом $є$ їхньою юридичною властивістю. Матеріальна шкода невіддільна від використання притаманним грошам функціональних властивостей і тому не потребує самостійної оцінки [10, с. 346-347]. Наведена позиція відносно кваліфікації збуту підроблених грошей у поєднанні з заволодінням чужим майном підтримав і Пленум Верховного Суду України, в одній із постанов якого наголошується, що заволодіння особою внаслідок збуту підроблених грошей чи державних цінних паперів чужим майном додаткової кваліфікації за 
статтями, що передбачають відповідальність за викрадення майна, не потребує [3, с. 91].

Деякі науковці дотримуються іншої точки зору та вважають, що заволодіння чужим майном унаслідок збуту підроблених грошей чи цінних паперів потребує кваліфікації за сукупністю злочинів [15, с. 175; 16, с. 47-48]. Саме цей погляд видається найбільш прийнятним. За такого підходу уникаються деякі спірні моменти в наведених вище твердженнях науковців, а саме: а) неврахування того, що збут може бути й безоплатним, а отже, шкода відносинам власності завдаватися в разі збуту буде не завжди; б) неврахування різниці в конструкції складів злочинів, яка полягає в тому, що підроблення та збут $є$ закінченими з моменту вчинення цих дій, а викрадення - з моменту заволодіння чужим майном, отже, шкода, спричинена відносинам власності, залишається за межами кваліфікації; в) неврахування того, що випливає з попереднього, але потребує окремого зазначення в силу своєї важливості, а саме спричинення шкоди відносинам власності в результаті заволодіння чужим майном у разі збуту підроблених грошей чи цінних паперів.

I, нарешті, відносно наведеного положення з вищезгаданої постанови Пленуму Верховного Суду України. Вбачається, що до однотипних суспільно-небезпечних діянь повинні застосовуватися однакові правила кваліфікації злочинів. Логічно з цього постає необхідність застосування єдиних правил кваліфікації кримінально караних підроблень незалежно від предмета підроблення. 3 огляду на це дещо суперечливою видається позиція Пленуму. Так, у п. 20 Постанови від 25 грудня 1992 р. № 12 наголошується на тому, що підробка документів з метою подальшого їх використання у шахрайстві й використання в разі шахрайства завідомо підробленого документа диспозицією статті, що передбачає відповідальність за шахрайство, не охоплюються й повинні окремо кваліфікуватися за статтею, що передбачає відповідальність за підроблення документів [17, с. 142]. Стосовно заволодіння майном під час збуту підроблених грошей чи цінних паперів наводиться діаметрально протилежне роз'яснення. Але ж по суті гроші й цінні папери $\epsilon$ різновидами документів.

Таким чином, дії винного, який підробив гроші або цінні папери, а згодом їх збув, заволодівши водночас чужим майном шляхом обману чи зловживання довірою, потребують кваліфікації за сукупністю злочинів, а саме за ст. ст. 190 й 199 КК. За такого підходу кримінально-правову оцінку отримає шкода, яка спричиняється відносинам власності в результаті оплатного збуту підроблених грошей чи цінних паперів. 3 огляду на це видається доцільним унести відповідні зміни в п. 15 постанови Пленуму Верховного Суду України «Про практику розгляду судами кримінальних справ про виготовлення або збут підроблених грошей чи цінних паперів» від 12 квітня 1996 р. № 6.

Цілком логічно, що небуде кваліфікації за сукупністю, коли особа, що збуває підроблені гроші, й особа, яка їх придбає, знають про їх підробленість. У такому випадку немає основної ознаки викрадення, а саме протиправного вилучення чужого майна проти волі власника. Дії обох необхідно кваліфікувати за ст. 199 КК, одного як збут, а іншого - як придбання підробленої валюти.

В аспекті, що досліджується, окремого розгляду потребує питання кваліфікації підроблення докумен- тів з подальшим їх використанням (ст. 358 КК), спрямованим на заволодіння чужим майном (ст. 190 КК). На практиці часто виникають складнощі під час кваліфікації подібних дій.

Висновки. Ст. 358 КК є винятковою за конструкцією у порівнянні з іншими кримінально караними підробленнями. Ї̈̈ винятковість полягає в передбаченні в окремій частині статті відповідальності за використання завідомо підробленого документа. В разі кваліфікації подібних випадків необхідно дотримуватися описаного вище правила, що підроблення, поєднане з подальшим використанням підробки задля заволодіння чужим майном, потребує кваліфікації за сукупністю злочинів, а саме за підроблення й відповідний злочин проти власності. Для розв'язання означеної ситуації за умови, що завідомо підроблений документ використовує особа, яка не брала участі в його підроблені, слід виходити з того, що використання завідомо підробленого документа $\epsilon$ способом учинення шахрайства, і додаткової кваліфікації за ч. 3 ст. 358 КК не потребує.

Окрім підроблення, спрямованого на подальше заволодіння чужим майном, підроблення може використовуватися також для приховування вчиненого раніше викрадення. У кваліфікації подібних випадків слід дотримуватися загального правила, що, коли підроблення вчиняються з метою приховування раніше вчиненого злочину, то кваліфікувати вчинене необхідно за сукупністю: за раніше вчинене й нормою, що передбачає відповідальність за підроблення.

I наостанку хотілося б зауважити, що нехтування загальними правилами кваліфікації, виробленими в теорії кримінального права, і правилами кваліфікації злочинів, які вчиняються підробленням, зазначеними в цьому розділі, може призвести до неправильної кваліфікації дій винної особи або навіть притягнення невинного до кримінальної відповідальності.

\section{Література}

1. Сергеева Т.Л. Борьба с подлогами документов по советскому уголовному праву. Москва-Ленинград : Изд-во Академии Наук СССР, 1949. 146 с.

2. Уголовный кодекс Республики Беларусь. Текст Кодекса по состоянию на 20 марта 2003 г. 288 с.

3. Про практику розгляду судами кримінальних справ про виготовлення або збут підроблених грошей чи цінних паперів : Постанова Пленуму Верховного Суду України від 12 квітня 1996 р. № 6. Постанови Пленуму Верховного Суду України (1963-2000) / За заг. ред. В.Ф. Бойка. Т. 2. Київ : А.С.К., 2000. С. 89-92.

4. Навроцький В.О. Теоретичні проблеми кримінально-правової кваліфікації. Київ : Атіка, 1999. 464 с.

5. Про судову практику у справах про контрабанду та порушення митних правил 6 Постанова Пленуму Верховного Суду України від 26 червня 2005 р. № 8. Вісник Верховного Суду України. 2005. № 6. С. 10-13.

6. Про судову практику в справах про контрабанду та порушення митних правил : Постанова Пленуму Верховного Суду України від 26 лютого 1999 р. № 2. Постанови Пленуму Верховного Суду України (1963-2000) / За заг. ред. В.Ф. Бойка. Т. 2. Київ : А.С.К., 2000. С. 83-88.

7. Советское уголовное право. Особенная часть. / Под ред. Г.А. Кригера, Б.А. Куринова, Ю.М. Ткачевского. Москва : Изд-во Моск. ун-та, 1982. 472 с.

8. Гришанин П.Д., Журавлев М.П. Преступления против порядка управления : лекция. Москва : Научно-исследовательский и редакционно-издательский отдел, 1963. 43 с. 
9. Багрий-Шахматов Л.В., Кострицкий И.Л. Проблемь анализа преступлений, связанных с платежными карточками. Актуальні проблеми держави і права. Збірник наукових праць. Вип. 14. Одеса : Юридична література, 2002. 168 c.

10. Бойцов А.И. Преступления против собственности. Санкт-Петербург : Юридический центр Пресс, 2002. 775 с.

11. Матышевский П.С. Преступления против собственности и смежные с ними преступления. Киев, Юринком, 1996. $240 \mathrm{c}$.

12. Гончаров Д. Квалификация подделки документов. Законность. 2000. № 12. С. 12-13.

13. Борзенков Г.Н. Ответственность за мошенничество (вопросы квалификации). Москва : Юридическая литература, 1971. 168 с.

14. Никулин С. Уголовная ответственность за изготовление либо сбыт поддельных денег или ценных бумаг. Законность. 1995. № 8. С. 7-13.
15. Волженкин Б.В. Экономические преступления. Санкт-Петербург : Юридический центр Пресс, 1999. 312 с.

16. Скляров С. Как квалифицировать последствия сбыта поддельных денег или ценных бумаг. Российская юстиция. 2002. № 10. С. 47-48.

17. Про судову практику в справах про корисливі злочини проти приватної власності : Постанова Пленуму Верховного Суду України від 25 грудня 1992 р. № 12. Постанови Пленуму Верховного Суду України (1963-2000) / За заг. ред. В.Ф. Бойка. Т. 2. Київ : А.С.К., 2000. С. 136-148.

Щирська В. С., кандидат юридичних наук, доцент кафедри кримінального права та кримінології факультету підготовки фахівців для органів досудового розслідування Одеського державного університету внутрішніх справ 